Journal of Business and Tourism

Volume 05 Number 01

January - June, 2019

\title{
Under-Utilization of Women in the Labor Market of Pakistan
}

\author{
Mariam Sohail \\ PhD Scholar, Superior University, Lahore \\ mariamsohail10@yahoo.com \\ Muqqadas Rehman \\ Lecturer, Hailey College of Commerce, Punjab University, Lahore \\ iluvnabi.saaw@gmail.com \\ Chaudhary Abdul Rehman \\ Professor, Business School, Superior University, Lahore \\ Email: ceo@superior.edu.pk
}

\begin{abstract}
The aim of this study is to find out the reasons which stop the educated women form utilizing their professional skills in Pakistan.A sample of twelve females is selected, out of which six are doing jobs in different sectors of Pakistan and six are unemployed but having professional graduation and masters degrees. Interviews are conducted with the participants. Findings indicate that culture and societal behavior, parents/family, male dominancy, bad working environment, long working hours, distant jobs, conveyance, safety issues, job discrimination, disinterest, household tasks, work-life balance are the main hurdles which stopwomen from doing jobs. All respondents agree that Islam does not stop women from jobs. Mostly, women prefer teaching profession because of less time and better working environment. Economy of the Pakistan will grow if educated women start utilizing their talent in the job market.
\end{abstract}

Keys Words: Women, Job, Education, Culture, Religion.

\section{Introduction}

\section{Statement of the Problem}

This paper highlights the women who have completed their professional graduation and master's degrees such as doctors, engineers, accountants, lawyers etc. but they are sitting at home. They are not utilizing their professional skills to serve Pakistan. They are either single not being permitted to go out for a job or married not getting permission from their husbands. This is actually the wastage of female capital in Pakistan. Pakistan is considered a male dominating society. In the past, females were not allowed to join schools for getting education in Pakistan because ofthe cultural factors. Therefore, most of the Pakistani women were uneducated and untrained. Now the scenario has changed. Women are encouraged to get education in Pakistan because people have recognized the significance of education. But the problem is that after completing their professional degrees, females do not utilize their skills in different sectors of the economy.

\section{Purpose of the Study}

The main purpose of the present study is to determine the reasons because of which educated women stay at home even after getting professional education. It is expected that the current 
study will add to the literature. We will come to know about the main hurdles which stop women from doing jobs and why specific professions are considered appropriate for women. What are the suggestions to solve the problems faced by women in going out for a job and what will be the effect on the economy of Pakistan if educated women are wasting their skills by sitting at home?

\section{Significance of the Study}

The educated women can contribute to the Gross Domestic Product of Pakistan because females are about the fifty percent of the total population of Pakistan. If such a huge population is not utilizing their skills after getting professional degrees, the economy of Pakistan will badly suffer. The main focus of this article is to highlight the problems which stop the women from starting their jobs after completing their professional education.

\section{Rationale of the study}

Many studies have been conducted on the education of women but there has been very little research done on employment issues of women in the context of Pakistan. Under-utilization of women in the labor market is still an under-researched area in this context. Further research is needed to inquire the value of such a direction. In this article, research is done on some of the important obstacles which stop women from going out for jobs in an attempt to provide more information on this topic. The aim of this research is to confess the major role played by different factors in getting women unemployed and to suggest how these hurdles can be overcome.

\section{Research Method}

There are three types of research methods which can be used in any study i.e. quantitative, qualitative and mixed methods. Qualitative Research method will be used in this study because opinions, perceptions and experiences of participantsare required to gain in-depth information about the topic.

\section{Delimitations}

Only women are selected as a sample in this study which is delimitation of this study. Women are selected because they can better share their point of views, opinions and experiences about the reasons which hinder them from doing jobs in the market and the problems which working are facing in the job market.

\section{Limitations of the Study}

The limitation of the study is the small sample size and the time constraint.

\section{Summary}

The purpose of this article is to explore the hurdles faced by women in Pakistan in starting their jobs after completing their degrees. Some women are forced to sit at home after completing their education by their parents and not to start any job. Some women start jobs but when they get married, they leave their jobs. It is considered that women should stay at home and do household chores and look after their children means they are just homemakers. Women should not go outside for doing job because it is the duty of men to earn money for the family.Socio-cultural factors, religion, male-dominancy, etc are some factors that restrictthe women at their homes.Working women have to face the issue of work-life balance and they have to perform double duties both at home and at their jobs which is also the reason females leave jobs after getting married.There is need to solve the job dilemma of the half population of Pakistan otherwise the skills of the educated women will keep destroying. If their skills will be used in the labor market, it will increase the national income and GDP of the country. Poverty will be reduced when educated women will contribute their professional skills in the market. 


\section{Literature Review \\ Review of Related Research}

Entrance of women in the different sectors of the economy has changed from recent decades. Women are taking the advantage of educational opportunities and they outperform in their studies. They are equally qualified as men but sometimes their qualification exceeds from them. A large number of women are trying to get full-time jobs in the market. There are still hurdles in the economy by which women are unable to enter in the market for jobs or to progress in the jobs which are better paid and have high status and likewise men discourage untraditional female dominated jobs. Regulations and developments to cut down these hurdles have been made and the organizations are implementing rules for equal opportunities but there is need of more improvement to support the regulations and to encourage helpful systems in the organizations (European Commission 2001, cited in Fagan \& Burchell, 2002). The faith on that that men and women have different wants, attitudes and capabilities to examine and manage a specific situation, is a distinguishing feature of males and females both at workplace and home (Ferree, 1990; Williams, 1999). One important cultural standard which prevents career growth of women is the faith on honor. Women are considered to represent the honor of the family and their purity and good character is highly respected and secured (Shaheed,1990). Women are supposed to stay at home and are not allowed to go out for jobs and usually males are considered the decision makers of their family and their careers are given priority over the career of females (SteilandWeltman, 1991).Socio-cultural beliefs hinder the women from going out for a job as women are considered the homemakers and men earn money for their families by doing jobs (Albee and Perry, 1998; Coltrane, 1996).

Women experience the basic household duties regardless of work obligations. Therefore, Women prefer to work in jobs with reasonable working hours such as to do low paid and part time jobs. The part time job is considered a best alternative for women having different household duties (Fagan andBurchell, 2002). Education, Health and care related employment sectors are dominated by the women. Other professions like engineering, Commerce and information technology are controlled by men. Women are under-represented in most of the professions (Crompton andSanderson, 1990; Ruberyand Fagan, 1993).Studies show that there is glass ceiling effect in the organizations and unofficial procedures for women to reach to the higher levels of management. Women who are successful in getting senior management positions have to pay high price for it. There are fewer chances to have children and more chances that they will remain single or divorced as compared to the same level male managers (Wacjman, 1998).On average, Women spend less time in their current jobs as compared to the men and both men and women do parttime jobs when they have less time. Women have high tendency to leave their jobs or to change their jobs when they have to look after their young children. Sometimes women switch their jobs to part-time jobs. Women are discriminated for employment in different sectors of the economy i.e. sales and restaurants even turnover rate is high for both men and women (Fagan \& Burchell, 2002).Most of the women leave their full-time jobs after marriage when they have to look after children. They start part-time jobs sometimes. Women have to face socio-cultural restrictions for working in Pakistan. These socio-cultural constraints stop women for going out for a job which originate from patriarchal settings. These constraints are also creating hurdles for working women. Pakistan society is based on patriarchal settings in which males are considered dominant and females are not allowed for jobs and to participate in development process. Our society support gender discrimination. Mostly, women are allowed to get education and training if this 
education matches or suits with the roles of women accepted by the society and gives them training as homemakers. As men are considered to earn bread and butter, the employment of women is less socially acceptable because by it the status of the family decreases but if the women get professional qualification like teachers and doctors and receive high pay, the society has no objection with their working (Isran, 2012). Women are considered weak in a society and it is duty of men to protect them from the evils or harms of the society. Men can deal easily with the work burden and challenges of the job, so females are not allowed to go out for jobs and seek their career (Albee and Perry, 1998; Ferree, 1990). There are some socio-cultural constraints in the society which are creating hindrances for the women for doing jobs and seek their careers (Hamid, 1993). When working women go out to earn money for themselves and for their families, people behave them in an awkward way. People stare at them, taunt them and even follow them. These male members of the society make it difficult for women to work in the society. Working women have to perform extra duties physically and psychologically. Even because of the hindrances faced by working women in our society, women are motivated to go out to earn bread and butter for the betterment of themselves, their families and their country (Cheema \& Yasmeen, 2003). To develop a country, women empowerment is compulsory but a country like Pakistan have to deal with many challenges because of cultural and religious aspects. Pakistan is an Islamic country but the implementation of true Islamic laws is not possible because Pakistan has patriarchal settings which are based on the old traditions of inferior and depending role of women. In this society, girls grow up by learning that they have to obey and do the work of men. Mostly, male members of the family make decisions which are related with the females like their jobs, their life partner selection, etc especially in the areas which are not developed. There are different elements responsible for the submissive role of women in Pakistan (Chaudhry et al2012).

Badawi (1971) describes in detail that how Islam has changed the lives of women and compares it with the position of women before Islam. He talks about various elements of Islamic empowerment. Bugaje (1997) explains about the rank of Muslim women and proves in the light of Quran and Sunnah that Islam provides more privilege to the women. Allah has not mentioned anywhere that women should not go out and stay at home. Islam is a complete code of conduct which gives more respect and honor to women. Preference theory anticipates that pay gaps and employment discrimination will continue to exist even in the twenty first century that men will continue to exceed in quantity from women in the highest jobs because men do more efforts to achieve them. Most of the employed women pursue complete work-life balance as compared to the men (Hakim, 2005).Women normally ask for less working hours in comparison with the promotions or high pay (Babcock \& Laschever, 2003). In some jobs long travelling is required on a short term notice like accountancy, architectureplumbing and sales jobs. Sometimes senior level managerial positions also demand more travel which may be long distance, uncertain timetable and regularly for a long time employee has to be away from home. Large travelling is required in some jobs like reporting of news, banking, airline and travel agencies. These jobs are not suitable for women who have children at home and can never be family-friendly (Farrell, 2005). The per capita income of the state increases when women with higher qualification are doing jobs which will lead to overall growth of the economy (Klasen, 2000).The International Labour Office explains that all types of the employment discrimination should be eradicated which is actually an inequality (Anker, 1998).Many women can achieve highest jobs in the organizations if employers agree to provide family-friendly working environment and other benefits like parental leave, part- 
time jobs, etc. (OECD, 2001). Women can easily manage their jobs with the family if employers are providing family-friendly environment. In order to decrease the dependence of women on men financially and to increases the bargaining position of women within and outside the home, it is necessary that women should be allowed to enter freely in the jobs market and access the credit (Isran and Isran, 2012).

\section{Summary}

There are large numbers of educated women in our society but they have hurdles in getting jobs in the market. It is considered that women are the homemakers and to earn livelihood is the duty of men. Men have the authority to make the decisions of their family. They think their careers are more important as compared to women and women should stay at home because of household chores and they have to look after their children. Women can do part time jobs. There are specific professions which are considered appropriate for women like teachers, nurses and doctors. There are socio-cultural barriers which stop women from jobs and if women start jobs, they are discriminated at the workplace. There is need to allow women for the jobs in every field.

\section{Research Methodology}

\section{Research Questions}

The research questions in this study were: 'What are the reasons which stop women from doing jobs?', 'What are the problems which working women are facing?', 'Why specific professions are considered suitable for the females?' and 'How the economy of Pakistan will be affected if educated women are not doing jobs?'

\section{Setting}

Face-to-face, semi-structured, individual interviews were conducted with twelve participants. Software NVIVO version 10 was used for data analysis. All the transcriptions were recorded and themes were made in the Software NVIVO.

\section{Population}

Population of the study was the educated females. The sample size was twelve. Half females were working in different fields while half were not doing jobs. Purposive sampling was used. Respondents were selected from Lahore city only.

\section{Data Source}

Primary research was conducted using interview schedule. Data was collected from fifty percent females who had masters or graduation degrees and were not serving any employment sector of Pakistan and fifty percent females who were employed in different sectors.

\section{Ethical Considerations}

Full consent was obtained from the respondents before interviews. Participants were informed about the purpose of the research before collecting data. Only the data related to the research questions was collected and no personal information was asked from the participants.

\section{Research Design}

This article is based on interpretivism approach in which interviews were conducted with females. Perceptions, opinions and experiences of women were required to get more information on the topic of under-utilization of women in the labor market of Pakistan. Moreover, this study explores the obstacles faced by educated women in getting jobs.

Participants were contacted through telephone to determine their eagerness to participate, and interviews were organized. All the interviews were conducted in Urdu language and then translated into English. The interview schedule had two parts: one was demographic characteristics of respondents and second was open-ended questions that were asked of all 
participants. All the interviews conducted were transcribed from recording for the analysis of data. The style of transcription used was de-naturalism.

\section{Interview Instrument and Protocol}

The instrument used to collect the data from the participants wasInterview Protocol.To achieve research objectives semi-structured interviewing method was used.

\section{Data Analysis Strategy}

To analyze the data, thematic analysis was used. Thematic analysis is a qualitative technique which is used to identify, analyze and report themes from the data (Braun and Clarke, 2006).

\section{Summary}

Qualitative research method was used in this study and instrument was the interview protocol. Purposive sampling was used in this research. Interviews were conducted with the twelve participants and interviews were recorded. Six participants were employed and doing jobs in different sectors and six were educated but not serving any sector of Pakistan.

\section{Research Findings \\ Participants}

Twelve interviews were conducted with the females out of which half were unemployed and half were serving in different sectors of the economy. The participant's age vary from twenty five years to fifty years. Half of the respondents were married and half were single. Participants have graduation, masters and higher degrees in different fields which brings variety in sample. Each participant was asked ten questions and their answers were recorded.

\section{Data Analysis Strategy}

Interviews were conducted with the twelve participants and recordings were made using a taperecorder. Later recordings were transcribed. For the analysis of transcriptions, thematic analysis was used. This paper is based on the themes which were extracted from the transcriptions of the participants.

\section{Culture and societal behavior}

First question which was asked from the participants was their opinion about the culture and societal behavior which hinder women to pursue and progress and in their careers. Almost all the respondents agree that it's the culture and society which stop women from doing jobs because it is considered that to earn money is the duty of men and women are the homemakers, they have to take care of their children and to do household tasks. Sometimes, women get permission for working after completing their professional degrees but sometimes they are not allowed to go out but to stay at home. It depends the on the mindset of the people. If people believe that women should sit at home and should take interest in household tasks, they will never allow their women to go out for utilizing their professional skills in the labor market even they are highly qualified and want to do jobs.

"In fact from cultural point of view the family pressure, children responsibilities, gender and parda concerns are the factors which stop women to have jobbed." (Ms. A)

One respondent stated that now women are bold and awareness has come through the media. But still there are some families which do not allow women for jobs when they complete their studies. Parents think that their main responsibility is to marry their daughter. Sometimes, women are also not interested in jobs because they think they have more duties at home. One participant said that women are allowed for jobs in some areas of a country which are liberal whereas they don't get permission in other areas. Our social and cultural scenario affects the pattern of how many women are working out there with what kind of jobs they are doing. 
Another respondent replied that the situation has changed. Now, women are getting permission for the jobs. Women go out to earn money and contribute financially to their families. They reduce the burden on men for earning bread and butter and share their responsibilities.

One respondent stated that societies in which women have their rights, there women can go out for earning money and a society where only men are considered to be responsible to earn income for their families, in these societies women are not supported to work outside the home.

Culture and societal behavior does matter. In a culture, where everyone enjoys freedom of their rights, where everyone has to earn his/her own livelihood, there women can easily go out for job. Whereas, a culture where employment opportunities are less either for males or females, a society where only one member has to earn money to accommodate his family, there when females go out for job, society looks down on them. (Ms. E)

One respondent stated that our society and culture discriminate women at workplace so females are discouraged to go out for a job. Employers prefer to hire males because they do not want to give maternity leaves to the females. It was responded that working women have less respect in our society because of negative working environment. Women have to work in a male dominated society so it's embarrassing for women to work in this situation.

According to the opinion of one female (Ms. G), the major hurdle is the culture and society which stop women from going out for a job. Most of the families do not allow their women for jobs in our society but some families give permission to the women for working.

In my opinion societal behavior is a real factor behind the very low share of educated women in the job market. There are many so called cultural and social taboos behind this dilemma. Overall the women are not welcomed in the job market of our country although there is a slight change as some families do support their daughters and sisters to have job but overall the situation is still worse in our society.(Ms. G)

It was stated by one respondent that some people allow women for job because they are not financially settled and sometimes people who are well-off do not allow women for jobs. It depends on the financial situation of the family. One woman responded that culture or society does not stop women from jobs but the duties of women stop them because they have to look after their children and to do household tasks. If they start jobs, their personal life suffers.

\section{Islam}

Next question asked from the respondents was about their opinion on that religion stops women from jobs or not. All the respondents agree on that Islam never stop women from going out for a job but Islam always gives stress on getting education for both men and women. Women are allowed to work outside the home in Islam but they should cover themselves when they go out from homes. One participant stated that illiterate make wrong interpretation of religion in this regard. Another responded that there is no religion which stops woman from earning livelihood to support herself and her family.

Islam is a complete code of conduct which helps in every field of life. Islam gives women more rights.

"Islam never stops women from job but I am not sure about those who make religion a restriction for women. Islam is a code of conduct, a way of life and has given women many more privileges." (Ms. L) 
One participant responded that Islam does not stop women to earn money for themselves and for their children. Women can do jobs or business. Another respondent stated that in Islam women are supposed to look after house first but at certain times it talked about women doing jobs and even business so it is doable.

Islam doesn't stop women from jobs but the scholars having less knowledge of religion misunderstand the Islam. They mix up religion with the culture.

The religion itself is not the problem behind this dilemma. It's the so called religious scholars with low knowledge of Islam are creating problems as far as the jobs issue of women is concerned. With their little knowledge they always misinterpret the religion and confuse religion with culture and which in result makes their followers confuse too. (Ms. G)

One participant replied Islam doesn't compel women to stay at home and not go outside for jobs. If woman needs job to support her family and children, she can go outside for job by covering herself. Islam gives permission to them.

\section{Family/parents}

Next question asked from respondents was about their opinion on that the parents or family stop women from going out for a job or not. One respondent says that some parents allow their daughters to go out for job when they complete their studies but some parents say that education is compulsory for women, not the job. When their daughters get professional degrees, they do not allow their daughters to utilize their professional skills in the relevant fields because they are more interested in their marriages.

Well, the case is fifty-fifty. Some parents encourage their daughters to study well and pursue jobs. Some encourage studying only. It depends what the parents have in their minds. They want to protect them from the social evils or maybe they want them to get settled in their lives as soon as possible.(Ms. L)

One response was that mostly parents do not allow women for higher studies because they think women should get married and perform duties of home. There is need to change such psychology of the people. The final destination of the women is not marriage. Job is compulsory for women. Two participants stated that parents and husbands do not give permission of jobs to the women because they think women are their responsibility. After marriage, women are not getting permission for jobs from their husbands because they think women have more duties at home such as to take care of their children and to do household tasks. One participant's opinion was that families, who have lack of wisdom, trust and awareness, they stop women from education and job but educated people never stop women from going out and doing the kind of work they like. One response was that few cultural taboos may hurls in women career. Some families believe that it will be disrespect for them that if their women go outside from home for some job. So this is a reason that some conservative parents do not allow the women for a job. They prefer women to sit at home and do household tasks. Therefore, it's the mindset of the parents because of which they don't allow women for jobs.

Another participant responded by saying that in a conservative society like our many families limit their women to household activities even after they give their women high quality education. Most of the families think that it will defame the family reputation if their women will go out for job so they always prefer for the women not have job after completing their studies.

One participant stated that we are living in twenty first century but people are still conservative. They have old image that men are breadwinner and women have to perform duties of home and 
take care of children. Men will go out for jobs to earn money for their children and family and women have to live within boundaries of home. One participant responded by saying that it is a bad luck of women that they are not getting permission for jobs after completing their education. Women need support of their parents and husband for doing jobs. One response was that women start jobs when they complete their education but they have to leave jobs when they get married. Husbands do not give permission to the females of doing jobs because they think that their first responsibility is to look after the children and manage their homes. Husbands and in-laws think that homes cannot be managed without them. One participant responded that mostly parents allow women for jobs. Women don't do jobs because of the societal conditions. People think that working women cannot give time to their families. The system of their homes will disturb. So better they don't go for job. But women can manage efficiently their homes along with their work. Some parents or husbands don't allow for office jobs.

One response was that family support counts a lot. Women can do jobs if their families support them. Some families are not giving permission to their daughters because of the security issues, work burden and political working situation.

Some good educated families too don't allow their daughters to go out for job keeping in view their safety, the work pressure, political work environment, etc. I myself am a working lady but I don't permit my sisters who have completed masters to do job. It's all because of work load, work stress and condemnable political environment. Some bad political games are practiced in our society. Those can't be eliminated from our society. (Ms. E)

\section{Male Dominancy}

Participants were questioned that male dominancy stops women from jobs or not. One participant says that we have a society in which males are dominant. They don't want females to do jobs. They don't give permission for office jobs. They say if you want to do job, go for teaching. Another response was that being husbands or brothers or bosses, men like to dominate whether it's fair or not. One participant stated that males can never stop women from going out for jobs even they are dominant. Another response was that men are always preferred in our society for jobs and women are given second priority even their education and experience are equal. The reason of preference is the more responsibilities of women because of which employers hire men instead of women. One response was that in our society men are superior and they have controlling authority. Men are considered to go out in search of money and women are supposed to stay at home and look after the homes. This is the main reason behind the very low rate of women having job in our society. One woman responded that men have dominating authority in our society; they do not want to see women equal to men. They think that it's our duty to earn money and provide food to women. The duty of the women is considered just to stay at home and care their children and to do household tasks. But now the trend is changing, some women are getting permission to support their family financially. One response was that no doubt we have a society in which males are dominant and they have formulated their own rules against the women and women are deprived from many of their basic or fundamental rights. Same is the case with issue of the jobs of women. Women are also not getting jobs because of this injustice.

According to one participant when women go out in search of jobs, men look at them in an awkward way. They behave as women are aliens in our society therefore women prefer to sit at home. Another participant responded by saying that even if we have society in which males are dominant, women should not have the fear of them. They cannot prohibit women from going out 
in search of jobs if women have courage to face all hindrances. One response was that we have a society in which males are considered strong and they do not want their women to go out for jobs because in this way they believe they will be disqualified. Another participant stated in a male dominant society, women are not allowed for the jobs in offices because there are more males in these jobs and women will have interaction with them which may lead to many problems.

\section{Workplace environment or particular job requirements}

In next question, participants were asked about their opinion on that working environment or specific work requirements stop women from jobs or not. One respondent stated that women are not allowed to work when the working environment is bad. Most of the women in Pakistan prefer to be the doctors and teachers but now there are vocational and technical institutions because of which women have entered in other fields. But sales jobs are disliked for women. Three participants stated that women are not going out for jobs because of the long working hours and when the job is at far distant from their homes. Sometimes women have conveyance problems because of which they prefer to stay at home. If women have conveyance they can easily do jobs even when the job is at distance from their homes. Women also have security issues when they are out for jobs. One respondent stated that women do not want to do the jobs in bad working environment. Office jobs have long work hours; therefore, females do not go for these kinds of jobs and prefer teaching. One responded that it is convenient for unmarried women to do jobs because they have fewer duties whereas married women have to look after their children and husband, therefore, they do not get permission for jobs. Employers do not provide facilities to the women having children and husband also do not support their wives; therefore, women are not interested in working.

One participant stated that working women have interaction with men and also harassment issues because of which their jobs are not liked. Women don't get permission of job because of late working hours. Women also have transportation problems.

Yes, indeed if there is more interaction with unknown men and the women are conscious of her veil. Secondly late sittings are not liked. Thirdly, harassment issues can also lead to an unfavorable environment for females in some cases.

Fourthly, transportation problem sometimes stop women from jobs because women have to face many problems when they use public transport. (Ms. A)

Another participant responded that long working hour jobs are not suitable for the females like banks, offices. When the working environment of the job is not good, females also do not go for jobs. Women also face harassment problems at work. According to the one participant, most of the job professions in our society are considered miss fit when it comes to women like driving, industrial work, construction field etc. because of their nature of work such as timings, particular dress code and the male dominant environment are the reasons stopping women from adopting such professions. One response was that women should manage their times to perform their duties efficiently both at homes and at jobs. Women should not leave jobs because of the bad working environment or hard job requirements. They should face these problems with courage.

Two women responded by saying that women are not allowed for the jobs because of the bad working environment, long working hours and location of the jobs is at distance.

\section{Obstacles}

Women were asked about the main reasons because of which women are not doing jobs. The two participants responded by saying that married women have the family and children because of which they are not doing jobs. Women are also discriminated during recruitment and also 
managers think that they are not competent as men. One participant responded that the main issue is the harassment at the workplace which stops the women from doing jobs. Another reason is that their family is affected by the job so they prefer to give time to their children and homes instead of doing jobs.Another respondent stated that not enough support from family, household chores and working hours etc. stop women from doing jobs. According to the two respondents, some women are never interested in job at all. Usually after marriage women stop working or household tasks indulge them for most of the time and ultimately no more interest left for the job. In our male dominant society women are mostly discriminated because of their gender even though they have qualification but mostly are not selected. Parents do not give permission to their daughters for the jobs because of the security issues.

One woman responded that most of the women are discouraged in our society so they never pursue their will of having job even after having the required qualification because women are not considered safe in most of the job professions in our society and if some brave women consider that they should apply for particular jobs, there are much chances that they will be discriminated in selection. Another participant stated that our society, unsupportive working environment and parents stop the women from jobs. Parents think that they have the responsibility of marriage of their daughters; they don't allow them for jobs. After marriage, women have to look after their children and to do household tasks, so husbands also don't allow educated women for jobs. They have more responsibilities after marriage. One participant stated that societal behavior stops women from doing jobs but home environment is more important. Some families do not allow women to go out for a job because they think that environment of the society is not good. Another participant responded that women have transportation issue while doing jobs and secondly, they have more duties at home like children, husbands, household tasks because of which they do not get permission of jobs. One respondent stated that more responsibilities at home and discrimination at jobs are the reasons because of which women are not going out for jobs. Employers prefer hiring men because they think women have conveyance issues, job timing problems and maternity leaves, etc. One woman responded that some women do not start jobs because of their families and there is also unemployment in our society because of which women stay at home. There are some professions which are male-specific and females are not considered suitable for them.

\section{Problems faced by working women}

Respondents were asked about the problems faced by working women. Two respondents stated that major problem of working women is the work life balance issue. They cannot give time to their families because of their jobs.Another problem faced by working women is the discrimination at their jobs responded by one participant. Women are discriminated during hiring, while assigning job tasks and for promotions. Abilities of women are underestimated and males are preferred. Two participants responded that women have to manage their time and need boldness because they have to perform the double responsibilities, one of the jobs and other is of their homes. Three participants stated that working women have work-life balance issue. They have double duties of home and jobs. Out of three participants two stated that women also have harassment problems. They have to interact with the males and may have late sittings. Three participants stated that working women have more depression as compared to the unemployed women because they have to give time to their jobs and also to their families. Jobs of working women affect their personal lives. They have to divide the time between their jobs and families. 
Working women have conveyance issues when they use public transport and also job timing issues.

One participant reported that work-life balance and male dominancy at the workplaces are the problems faced by working women.

Female employees find difficult to balance their family and their work. Mostly children of such working ladies suffer a lot. The time their children needed to be spent them and cared about is utilized at their workplace. Then family pressure depresses her a lot for such imbalanced life. Due to male dominance and male unity at workplace blames for mistakes to females who are in less in number and it happens in those workplaces where usually job duties are not defined and

\section{Female professions} women ultimately had to suffer. (Ms. E)

Women were asked that why there are some female-specific professions means why women prefer some particular professions like teaching, doctors and nurses. Participants reported that doctor and teachers have respectful image in our society. In teaching profession women have less interaction with the males and less job timings. Women have to teach the kids only. Females have lack of public dealing in teaching. There is better environment in the schools where females work in a common place or hall or class, not separately build cabins and isolated work with males like in companies. One participant responded by saying that women working in other professions have more interaction with the males and women are not convenient working with men. Another participant responded that teaching and medicine are the professions which are preferred for women because these professions are not hard like other professions. Women have more respect and security in teaching and health-related sectors.

One participant stated that women prefer teaching jobs because time is flexible, they can easily manage their work and homes. Our society gives respect to the female teachers and doctors as compared to the public relation jobs. One respondent stated that women have now entered in every field and in the past there were specific professions which were preferred for the females. Both teaching and medicine are decent professions for women. Women prefer teaching profession because it has less working hours and summer and winter vacations. Female doctors are respected in our society because of the services they provide.

Teaching others and helping others are good and the most reputed profession. In schools/universities, working hours are less as compared to the timings at other workplaces, therefore females prefer such jobs. They can enjoy freely their summers and winter vacations. Regarding medicine, girls get independent in society and are highly esteemed in the public for her services. If she being a doctor is not allowed to go out to hospitals for work, she herself can open a clinic in her own house therefore families prefer such professions. (Ms. E)

One respondent stated that teaching is considered a decent and sophisticated profession for the females in our society. Women enjoy and feel happy to educate children and they have to spend less time in this job. Teachers are respected in our society. Women can work within specific boundaries in this job. Teachers can learn more knowledge while educating children.

\section{Suggestions}

Respondents were asked to give suggestions to overcome the hurdles women are facing in getting jobs. One participant responded that the key to success globally is that women should keep learning and always have a can-do attitude. People should think positive. Women should have job 
opportunities in all the fields of economy. Another participant stated that even in the presence of gender disparity, women should dare for doing jobs. They should try to adapt themselves according to the working environment. Gender discrimination should be eliminated from the society. One response was that women need to learn not to accept all the responsibilities. Family needs to share some of the responsibilities with them so that their burden can be reduced. Also, they could work part time. One participant stated that gender constraints should be eliminated. Perception of potential employers that females will take more leaves because of children responsibilities and may have timing issues etc. should be changed. Secondly, emotional issues also hurdle in females' hiring. One response was that women should be encouraged for jobs. Government, parents and women all should play their roles regarding this. Fifty percent jobs should be allocated for women. One woman stated that employers should not discriminate women or underestimate their silks and should provide them their rights. Government should provide more job opportunities for the females so they are encouraged for jobs. There should be clear job descriptions and equality of work both for men and women. Family should support woman if she is doing job. There should be safe working environment in which women feel secure.

Normally, teaching and health related sectors are preferred for the women. Women should also enter in other professions but there is need to understand Islam, women should have training, safe working environment, flexible job timings, transportation availability and family should also support women for the jobs.

In order to motivate the women to go out for jobs and to join many nontraditional professions, there are some factors to be implemented such as to make the people understand religion in the true sense, training of women, safety of women, reasonable job timings for women, transportation for women and last but not the least family support can bring and motivate the women to go for both traditional and non-traditional sectors of job. (Ms. G)

One participant responded that most of the working women have conveyance issues. Employers should provide pick and drop service to the working women. Environment of the workplace should be supportive so that females can do jobs there conveniently. Housemaids can be hired by working women to reduce the work burden. Another response was that educated women should be allowed to go out for a job to utilize their skills. Everything can be managed like children, household tasks, etc. Women should enter in all the fields. Working women can manage efficiently their homes. They have time schedule of every task of their lives. Women should be bold and show patience. Women have power to do everything. Government should provide more job opportunities for women and there should be proper jobs according to the qualification of females. Society, parents and government all should support women for doing jobs.

One participant stated that employers should provide day-care centers for the children of the working women. In this way, women can do jobs easily. If women have their own conveyance, they can go to the jobs without any difficultly. One respondent stated that proper platforms should be provided to explore the skills of women. Employment opportunities should be increased so that girls could easily hunt their jobs. Public and the government should support to bring on front their skillful work. Private and government organizations or companies should clearly define duties to its employee to stop them giving such blames to women in the last. In the name of religion, such disputes should be avoided which are not given in Islam but people claim that those are included in religion Islam. 
One respondent said that women should be allowed to do jobs. They should contribute to the family income by utilizing their skills. Government should provide more job opportunities for females other than teaching profession. Private employers should not discriminate women while hiring. We should look ahead to other developed countries and bring fruitful results with collaboration of males.

\section{Effect on economy of Pakistan of under-utilization of women}

Respondents were asked last question that how the Pakistan economy will be affected if educated women are not utilizing their skills in the labor market. One response was that educated women will have no contribution to the economy of Pakistan if they sit at home instead of doing jobs.

Another response was that if women are not going out for jobs after completing their education, they depend on their families. Per capita income and overall spending of a family will be affected. One participant stated that if educated women will come in the market, uneducated people will have fewer jobs because of the competition. This tendency will lead to the development of the economy.

Women are about the fifty percent of the population of Pakistan and when such a large number will sit at home and not utilize their professional skills in the market, how can we succeed. We will waste human capital and its related skills.

We will miss a major human capital, skills, specific traits, patience at work, soft skills etc. which are the basic requirements of some particular job slots. By making half population sit in home in the $21^{\text {st }}$ century how we can compete globally. Our manpower is our strength and we are working with half of our strength. (Ms. A)

One respondent stated that economy of Pakistan will not grow if educated and skilled women are sitting at homes. This is the wastage of human capital. We can develop when women will contribute their share in the economy. Another participant said that if educated women are not doing jobs and sitting at home, this will have negative effect on the Pakistan economy. They are actually wasting their skills. Women should do jobs and financially support to their families.

One woman responded that almost half of the population of Pakistan is not in the labor market because of this reason Pakistan is not progressing. Another woman said that it's actually injustice with the educated women who are not permitted for a job. Women should work side by side with men. Pakistan economy will grow if educated women are going out for a job. One respondent said that if every member of the family earns money now-a-days, hardly needs are being fulfilled. Our economy will progress and poverty will be reduced when educated females are doing jobs. They can earn money for themselves and for their children. Another participant stated that all educated women are not doing jobs because of this reason Pakistan is not progressing. In developed countries, every girl and child does job according to their abilities to meet their expenses.

One woman stated that when skills and talents of women would not be brought forefront, it will not lead us to a progressive state then. Observe the economic factors of the developed countries, there one can find that women had equally participated in increasing GDP of a country. Platforms of small industry like home industry for women would be productive and our country could export their hand made products. Educated women can guide uneducated women a proper channel of exporting products to other countries. 
Another participant said that participation of our educated women will contribute to the national income. Pakistan would become self reliable and independent if from a family not only males would earn but also females earn livelihood to reduce and share burden of expenses together. Economy of Pakistan will develop when women will utilize their skills in all employment sectors. Women are the best orators, speakers, chefs, etc so should not be underestimated by the society.

\section{Summary}

Participants were interviewed and analysis was done through thematic analysis. Respondents stated that culture, society, parents, male dominancy, poor working environment, specific workplace requirements and work life balance issue are the reasons because of which women stay at home instead of utilizing their talent and expertise in the labor market. Islam does not prohibit women from doing jobs.For the development of the economy of Pakistan, women should demonstrate their skills and knowledge in the market

\section{Discussion}

\section{Research Questions}

One of the main reasons which stop women from jobs is our culture and societal behavior. Many so called cultural and social taboos hurls in women career. Women are supposed to look after children and do household tasks. Working women have no respect in the society. Situation is still worst in some parts of our country. The family pressure on women, parda concerns and responsibilities of women are the factors which create hindrances in the women career. Overall, the trend is changing and women are being encouraged for jobs. Almost, all the respondents agree that Islam never stops women from going out for doing jobs. Islam is a complete code of conduct which gives more privileges to women. In fact, Islam gives permission to women of jobs and so called religious scholars wrongly interpret and confuse the religion with culture. In Islam women are allowed to go out for jobs by covering themselves. Islam emphasizes on the education of women. Some parents stop women from doing jobs and some parents or husbands allow them. Parents or husbands do not allow women for jobs because women are depending on them and they think that women have to manage their homes and look after children. It is the duty of men to earn money and women should stay at homes. If women will start doing jobs their homes will suffer. People who have lack of trust on women, they don't give job permission to women. Educated parents have awareness so they allow women for jobs. But sometimes even educated parents don't allow women for jobs because of the other factors like safety, work burden, political work environment, etc.

Male dominancy is also considered one of the main reasons which stop women from going out for jobs. We have a male dominant society in which males are considered superior and bread winner and women are home makers. Females are always given secondary importance. Men are preferred for the jobs even if women have same education and experience. Males don't want women to do jobs. They make rules in favor of men and against women which deprive women from their basic rights. When women are out in the job market, they treat and behave with them in a strange way and stare at them. But women should not afraid from men because they are the part of our society. Negative working environment also stop women from jobs. Particular job requirements like long working hours, distant jobs, interaction with men, late sittings, and transportation problems can also create hurdles for women in getting jobs. Discrimination during recruitment, workplace harassment, more home responsibilities, lack of interest, security issues, unsupportive workplace environment are the reasons which stop women from doing jobs. 
The main problem which working women have to face is the work-life balance issue. They cannot give proper time to their families and children. They have to perform double duties of jobs and homes. Women are also discriminated at jobs because of their gender and they are also discriminated for promotions. Working women have to face harassment issues because they have more interaction with unknown men. Women also have late sittings sometimes in office jobs. Working women have also transportation and job timing issues. Employed women have more depression because of overburden of duties. Teaching and health related professions are the specific professions which are considered appropriate for the women in our society. Doctors and teachers have respect in our society. These professions are considered sober and decent for women. Teaching is preferred by women because of following reasons: women have no interaction with men, they have to teach kids only, less job timings, summer and winter vacations, better working environment, and they can manage their homes easily. Doctors and nurses have respect in our society because they serve to the mankind. Now, women are also entering in other professions.

Women should keep learning and they should think positive. Women should dare for going out for jobs and they should adapt themselves. Women should show boldness. Women should be encouraged. They should raise their voice against gender discrimination. There should be equal jobs for women and men. Women and men should share their responsibilities with each other. Women can also work part time. The power of women should not be underestimated. There is need to change the thinking of the employers who discriminate women for jobs. There should be safe workplace environment and family should support women. Women should have jobs in all the sectors of the economy. Employed women can take help from servants. Pick and drop should be provided by employers to women. Women can contribute financially in the family's income. Quota for women jobs should be raised. There is need to understand religion in the true sense. Day care center facility should be provided by employers. Women should learn time management skills to manage both homes and jobs. Women should have permission for jobs from their parents or families.

Women should do jobs because women are about fifty percent of the population of Pakistan and when they will do jobs, per capita income and spending of a family will increase. Women will bring more money in the economy by serving in different sectors of the economy. Otherwise, we will waste the human capital. Economy will progress and poverty will reduce by employed women. GDP and national income will also increase. Women will no more depend on men if they start doing jobs and will be independent and self-reliable. To compete globally, women should be encouraged for jobs. Figure 1 represents the factors which are responsible for under-utilization of women in the labor market of Pakistan. These factors are actually the obstacles because of which women are not doing jobs in the market. Culture and Societal behavior, Unsupportive workplace environment, Household chores, Work life balance issue, Unemployment, Security issues, conveyance problem, male dominancy, family/parents, disinterest of females, jobs at long distance, gender discrimination, workplace harassment issues, and workplace timing issues are the hindrances which stop women from jobs. 


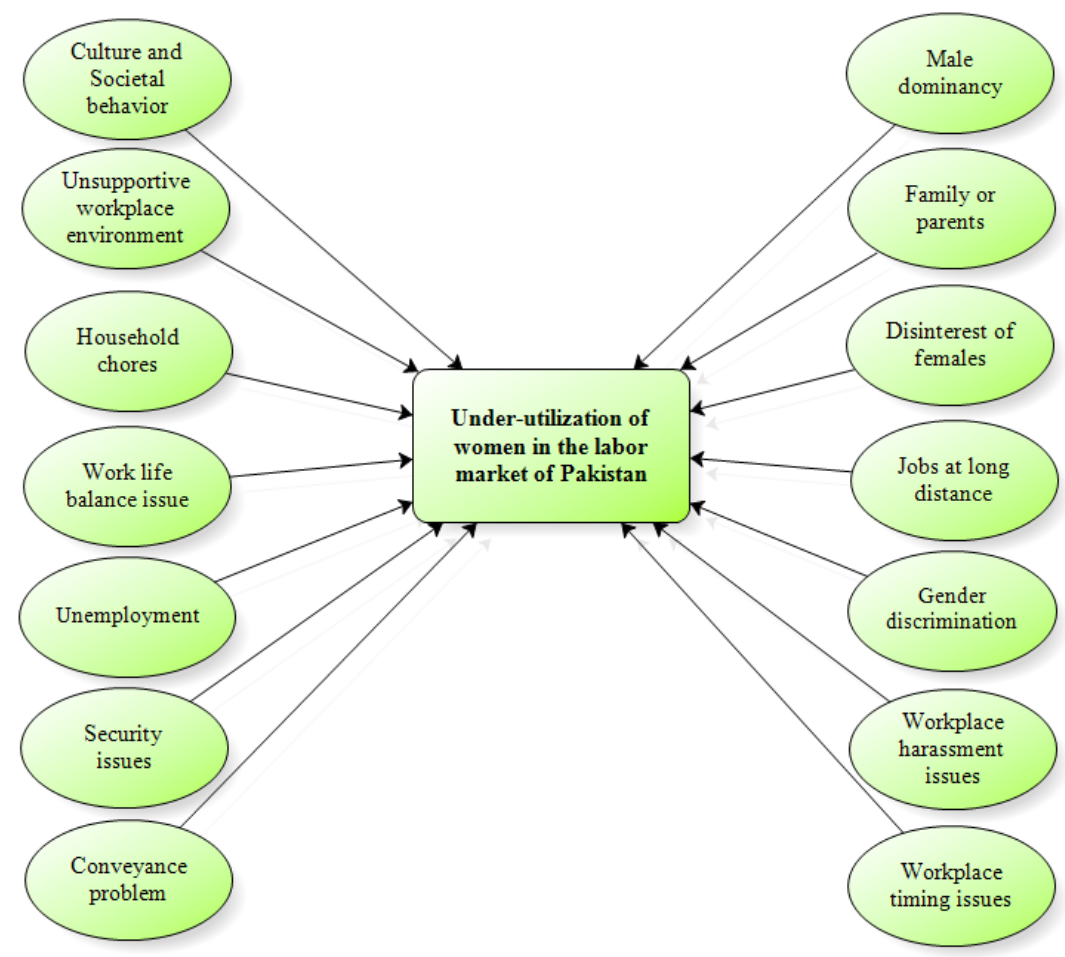

Figure 1: Under-utilization of women in the labor market of Pakistan Conclusion

Educated women have to face hurdles in going out for jobs such as socio-cultural barriers, parents/family, male dominancy, unsupportive work environment, work life imbalance, security issue, household chores, gender discrimination, unemployment, conveyance problem, disinterest of females, job timing issue, harassment issues, jobs at long distance but Islam does not stop women from going out in search of jobs. In our society teaching is considered appropriate for the women because of the less timing and best working environment and health related sectors are also preferred for the women because of the services they provide to the human beings. If all the educated women will enter in the labor market with their talent and skills, it will increase the national income and GDP of a country.

\section{Recommendations and Implications for Theory, Research and Practice}

To solve this dilemma, government, NGOs, private organizations and public all should play their role. Women are part of our society and they are almost fifty percent of the population of the Pakistan, we cannot ignore them. If all educated women start utilizing their skills in the economy, it will lift the growth of GDP of Pakistan.

- Women should be promoted to the higher positions in the organizations so that the other women are encouraged.

- Employers should notice that if managers are discriminating females at the workplace. Such gender-based discrimination should be eliminated.

- Transportation facilities should be provided to the working women by the government and private organizations. 
- Government and private organizations should provide the facility of day-care centers for the working women.

- Government should try to provide jobs at the doors of those women who cannot do work from outside their homes because of different reasons so that they could also support their families financially.

- Government should raise the job opportunities for the female by allocating special quota for them.

- Special institutes should be established for the females by the government where they have no interaction with the males such as Women post office, First Women Bank, etc.

- Primary education and basic health sectors should be declared only for females.

- There should real or practical implication of laws regarding gender equality at workplace, harassment, etc.

- Overall there is need to initiate a campaign nationally to educate our society that there is nothing wrong for the women to have job.

Small sample size is the limitation of this paper. More research is needed using large sample size to eliminate the limitation of the small sample size of this article. Quantitative research methods having large sample size can be used and results can be generalized. Future studies applying both quantitative and qualitative methods would also help.

\section{Summary}

Educated women have to face obstacles while going out for jobs. Sometimes parents or husbands do not allow them, sometimes culture or society is a barrier for them. Women are not utilizing their skills in the labor market because of the male dominancy, bad workplace environment, household tasks, conveyance and security issues, work-life balance issue, long working hours, and gender discrimination but Islam never disallow women from doing jobs. Teachers, doctors and nurses have more respect in our society as compared to the other professions. Economy of the Pakistan will grow if educated women fully utilize their skills in the labor market.

\section{References}

Albee, G. W., \& Perry, M. (1998). Economic and social causes of sexism and of the exploitation of women. Journal of community \& applied social psychology, 8(2), 145-160.

Anker, R. (1998). Gender and jobs: Sex segregation of occupations in the world. Geneva: International Labour Office.

Babcock, L.,\& Laschever, S. (2003). Women Don't Ask: Negotiation and the Gender Divide.Princeton University Press.

Badawi, J.A. (1971). The status of women in Islam.Al-lttihad, 8(2).

Braun, V., \& Clarke, V. (2006). Using thematic analysis in psychology. Qualitative research in psychology, 3(2), 77-101.

Bugaje, U. M. (1997). Women's empowerment and Islam. A Paper Presented at the Symposiumon Islam and Contemporary Issues, Organized by Movement for Islamic Culture \& Awareness, Nigeria.

Chaudhry, I. S., Nosheen, F., \& Lodhi, M. I. (2012). Women empowerment in Pakistan with special reference to Islamic Viewpoint: An empirical study. Pakistan Journal of Social Sciences, 32(1), 171-183. 
Cheema, M. A., \& Yasmeen, S. (2003). Problems of working women in export garment factories in Faisalabad-Pakistan. International Journal of Agriculture and Biology, 5(3), 279-280.

Coltrane, S. (1996).Family man: Fatherhood, housework, and gender equity. New York: OxfordUniversity Press.

Crompton, R., \& Sanderson, K. (1990). Gendered jobs and social change. Routledge.

Fagan, C., \& Burchell, B. (2002).Gender, jobs and working conditions in the European Union. Dublin: European Foundation for the Improvement of Living and Working Conditions.

Farrell, W. (2005). Why men earn more: The startling truth behind the pay gap--and what women can do about it. New York: AMACOM for the American Management Association.

Ferree, M. M. (1990). Beyond separate spheres: Feminism and family research.Journal of Marriage and the Family, 52, 866-884.

Hakim, C. (2005).Sex differences in work-life balance goals. In: Houston, D. (Ed.), WorkLifeBalance in the 21st Century (pp. 55-79). London: Palgrave Macmillan.

Hamid, S. (1993). A micro analysis of demand-side determinants of schooling in urban Pakistan. The Pakistan Development Review, 713-723.

Isran, S., \& Isran, M. A. (2012). Low Female Labour Participation in Pakistan: Causes and Consequences. Pakistan Journal of Social Sciences (PJSS), 32(2), 453-468.

Klasen, S. (2000). Does gender inequality reduce growth and development? Evidence from crosscountry regressions. World Bank Policy Research Report Working Paper No. 7.

OECD. (2001). Balancing work and family life: helping parents into paid employment.Employment Outlook, 2, 129-166

Rubery, J., \& Fagan, C. (1993).Occupational Segregation of women and men in the European Community.In: Social Europe Supplement, No. 3/93. Luxembourg, Office for Official Publications of the European Communities.

Steil, J. M., \& Weltman, K. (1991). Marital inequality: The importance of resources, personal attributes, and social norms on career valuing and the allocation of domestic responsibilities. Sex Roles, 24(3-4), 161-179.

Shaheed, F. (1990). Pakistan's women: an analytical description. Women Living under MuslimLaws, Asia Region Office.

Wajcman, J. (1998).Managing like a man. Women and Men in Corporate Management, University Park.

Williams, J. (1999). Unbending gender: Why family and work conflict and what to do about it.New York: Oxford University Press. 